\title{
KULTURA I ZRÓWNOWAŻONY ROZWÓJ - WYKORZYSTANIE NARZĘDZI PARTYCYPACJI ZAANGAŻOWANEJ
}

\author{
Abstract \\ CULTURE AND SUSTAINABLE DEVELOPMENT. A SUBJECTIVE OVERVIEW \\ OF THE USE OF PARTICIPATORY ENGAGEMENT TOOLS
}

The concept of sustainable development and the strategies of implementing sustainable development at the country, region and city level are not just empty words commonly used by politicians, public administration, or the media. The paper presents a long-standing global discussion on the concept itself and its main components. It also unfolds the increasingly intense attempts to devise strategies premised on sustainable development and to consider culture (in the very broad sense of the word) as the key determinant of development. This is illustrated by the description of the use of one of the tools of social participation - participatory engagement - based on case studies from the domain of culture.

SŁOWA KLUCZE: partycypacja społeczna, kultura w zrównoważonym rozwoju, kultura, dobrobyt społeczno-ekonomiczny

KEY WORDS: social participation, cultural sustainability development, culture, wellbeing

\section{Wstęp}

Na całym świecie można dziś obserwować coraz większe zaangażowanie społeczności lokalnych w zarządzanie przestrzenią, środowiskiem, planowanie działań podnoszących jakość ich życia. Powszechnie uznaje się, że to jedyny sposób, aby ludzie żyli w takim otoczeniu, jakiego pragną, i żeby czuli się jego częścią. Możemy powszechnie obserwować wykorzystywanie partycypacji społecznej przez władze administracyjne, które często same inicjują procesy partycypacyjne i wdrażają działania mające na celu aktywizację mieszkańców. Widać to najlepiej na przykładach małych społeczności. Dzięki zaangażowaniu wszystkich stron możliwe jest 
kreowanie środowiska życia, które satysfakcjonuje funkcjonujące w nim społeczności, prowadząc do silnej integracji na poziomie lokalnym. To zaangażowanie nie jest tylko modą, trendem cechującym zachowania współczesnego świata, ale wynika wprost z realizacji polityki zrównoważonego rozwoju, która wyznacza dziś zarówno kierunki polityki Unii Europejskiej, jak i wielu innych krajów. Stwarzanie możliwości podejmowania przez obywateli różnorakich działań jest celem budowania społeczno-ekonomicznego dobrobytu, który w literaturze światowej nazywa się ogólnie wellbeing i wykorzystuje do definiowania kultury ${ }^{1}$. W tym rozumieniu kultura jest działaniem samym w sobie, jest podstawą i fundamentem, na którym opierają się wszelkie działania, pozornie niemające z nią nic wspólnego, jest tym, co scala wszystkie wyodrębniane przez lata składowe zrównoważonego rozwoju.

Administracja publiczna, wdrażając koncepcję zrównoważonego rozwoju, przede wszystkim tworzy warunki do podejmowania działań przez organizacje i instytucje, osiągając tym samym wyznaczone wcześniej cele strategiczne. Stąd też instrumenty i narzędzia, o których jest mowa poniżej, są rozwijane jako tzw. dobre praktyki, wpisywane do planów strategicznych pod ogólnym pojęciem wdrażania instrumentów partycypacji społecznej. Są zmienne, zależne od zaangażowania grup czy organizacji społecznych, podlegające modzie i modyfikacjom oraz trudne do jednoznacznego zaklasyfikowania. Możemy zaobserwować z jednej strony wiele inicjatyw spontanicznych, z których większość nie daje się jednoznacznie zaklasyfikować i ciągle się modyfikuje, $z$ drugiej zaś próby ich nazywania i wprowadzenia jako narzędzi zarządzania. Dobre praktyki są opisywane, analizowane i rozpowszechniane w celu adaptowania przez kolejne grupy, ale tylko niektóre z nich stają się stale wykorzystywanymi narzędziami zarządzania zrównoważonym rozwojem. Organizacja niniejszego tekstu wynika z chęci bliższego przyjrzenia się tym instrumentom i narzędziom, które tworzy w praktyce. Każdy z podjętych wątków został ograniczony do krótkiego omówienia, gdyż każdy wydaje mi się niezbędny do analizowania podejmowanej problematyki. Tekst jest zatem podzielony na kilka części:

1. W stronę zrównoważonego rozwoju - między polityką a strategią. Zostały tu przywołane i krótko skomentowane najważniejsze dokumenty związane ze współczesną koncepcją zrównoważonego rozwoju oraz ich przeniesieniem do dokumentów strategicznych, wyznaczających kierunki rozwoju państw. W ostatniej części tego fragmentu odnoszę się do kultury, jako że stanowi ona przedmiot mojego głównego zainteresowania.

2. Partycypacja społeczna jako instrument zarządzania. Dokumenty ratyfikowane przez poszczególne państwa na poziomie ONZ czy Unii Europejskiej prowadzą wprost do tworzenia strategii rozwoju, a wśród instrumentów zarządzania, wytyczanych przez zasady good governance i multilevel-partnership (rozumiane jako szeroki udział społeczeństwa w zarządzaniu państwem), wymienia się m.in. partycypację społeczną.

${ }^{1}$ Zob. przywoływane w dalszej części, np. Culture: Fourth Pillar of Sustainable Development, UCLG 2010, http://www.agenda21 culture.net/documents/culture-the-fourth-pillar-of-sustainability [odczyt:12.10.2016]. 
3. Wykorzystanie narzędzi partycypacji zaangażowanej - wybrane przykłady. Ta część jest próbą pokazania, jak w praktyce wykorzystane zM3pctKYsą narzędzia partycypacji społecznej. Wybór został uzasadniony możliwością zaprezentowania wielu przykładów z dziedziny kultury, gdzie aktywność społeczna będąca jednym z ważniejszych kryteriów jest bardzo duża, a także powtarzalnością wykorzystywania tego narzędzia.

\section{W stronę zrównoważonego rozwoju - między polityką a strategią}

Sformułowanie zrównoważony rozwój przypisywane jest osobie osiemnastowiecznego starosty saksońskiego Hansa Carla von Carlowitza, który odniósł je do zasady postępowania wobec lasów, jakimi zarządzał. Jego ideą było utrzymywanie istnienia lasu - sformułował i realizował konsekwentnie zasadę wycinania tylko takiej liczby drzew, jaka może urosnąć zamiast nich we właściwym czasie. Model przyjął się w leśnictwie całych Niemiec, w późniejszym czasie był adaptowany również do innych krajów.

Aby mówić o współczesnej koncepcji zrównoważonego rozwoju, należałoby się cofnąc do lat siedemdziesiątych (prac Komisji Rzymskiej) czy osiemdziesiątych XX wieku, kiedy to Międzynarodowa Unia Ochrony Przyrody i jej Zasobów (Union for the Conservation of Nature and Natural Resources IUCN) przedstawiła Światową Strategię Ochrony Przyrody (World Conservation Strategy)², w której za główny cel uznane zostało stworzenie warunków, które będą przyczyniały się do trwałego rozwoju przez ochronę żywych zasobów przyrody. W następnych latach różnorakie gremia światowe podejmowały ten temat w kontekście ochrony zasobów naturalnych właśnie. Punktem zwrotnym dla współczesnej polityki, w tym również kulturalnej, i tworzenia instrumentów zarząadzania zarówno na poziomie administracyjnym, jak i w ich następstwie - na poziomie organizacji, jest powstały w 1987 roku raport $\mathrm{Na}$ sza wspólna przyszłość (Our common future) przygotowany przez Światową Komisję ds. Środowiska i Rozwoju, potocznie zwaną Komisją Brundtland, pracującą od roku 1983 pod patronatem ONZ33. Podstawowa definicja zawarta w Raporcie, mówiąca o tym, że zrównoważony rozwój to proces mający na celu zaspokojenie aspiracji rozwojowych obecnego pokolenia w sposób umożliwiający realizację tych samych dążeń następnym pokoleniom, stanowiła podstawę nie tylko rozwoju koncepcji, ale i wypracowywania instrumentów oraz narzędzi jej wdrażania. Aby rozwój był rzeczywiście zrównoważony, wszystkie systemy gospodarcze, społeczne i środowiskowe muszą być jednocześnie zrównoważone i muszą zachodzić między nimi interakcje. $\mathrm{W}$ dokumencie zostały podkreślone trzy najważniejsze dziedziny, w których powinien następować postęp. Są to:

2 World Conservation Strategy: Living Resource Conservation for Sustainable Development, International Union for the Conservation of Nature and Natural Resources, Gland 1980.

3 WCED Brundtland Commission: Our Common Future, Oxford 1987. 
- Wzrost gospodarczy i równomierny podział korzyści

- Ochrona zasobów naturalnych i środowiska

- Rozwój społeczny.

Bezpośrednim następstwem działalności komisji było zwołanie Szczytu Ziemi w 1992 roku w Rio de Janeiro oraz uchwalenie kolejnych wytycznych programowych, jak np. Deklaracja z Rio de Janeiro $w$ sprawie środowiska i rozwoju z 1992 roku $^{4}$, Agenda 215 , czyli plan działania dla Narodów Zjednoczonych, rządów i grup społecznych. Kolejny Szczyt Milenijny Organizacji Narodów Zjednoczonych w roku 2000 zdefiniował Milenijne Cele Rozwoju, które powinny zostać osiągnięte do 2015 roku. Znalazły się tu:

- Wyeliminowanie skrajnego ubóstwa i głodu

- Zapewnienie powszechnego nauczania na poziomie podstawowym

- Promowanie równości płci i awansu społecznego kobiet

- Ograniczenie umieralności dzieci

- Poprawienie opieki zdrowotnej nad matkami

- Ograniczenie rozprzestrzeniania się HIV/AIDS, malarii i innych chorób

- Stosowanie zrównoważonych metod gospodarowania zasobami naturalnymi

- Stworzenie globalnego partnerskiego porozumienia na rzecz rozwoju.

Kolejny Światowy Szczyt Ziemi odbył się w roku 2002 w Johannesburgu. Stał się okazją do rozszerzenia idei poza ogólnoświatowe porozumienia i wprowadzenia nowych form partnerstwa, gdzie nie tylko instytucje rządowe, lecz także społeczeństwo obywatelskie na równi otrzymały prawo, ale i obowiązek zaangażowania się w realizację zrównoważonego rozwoju. W tym samym roku jeszcze Zgromadzenie Ogólne ONZ ustanowiło lata 2005-2014 Dekadą Edukacji dla Zrównoważonego Rozwoju, nazywaną później także Dekadą Zmiany. Wśród głównych zadań postawionych przed państwami członkowskimi znalazły się propagowanie zrównoważonych zachowań, inspirowanie krytycznego i twórczego myślenia, pozwalającego znaleźć rozwiąanie problemów uniemożliwiajacych trwały rozwój ${ }^{6}$.

Szczyt Rio +20, zorganizowany ponownie w Rio de Janeiro w 2012 roku, podczas którego dyskutowano m.in. kwestie rozwoju przyjaznych środowisku gospodarek jako narzędzia walki z ubóstwem, ochronę mórz i oceanów przed nadmierną eksploatacją, zrównoważone rolnictwo i bezpieczeństwo żywieniowe, tworzenie zrównoważonych i lepiej funkcjonujących organizmów miejskich, zakończył się przyjęciem dokumentu Przyszlość jakiej chcemy (Future We Want) ${ }^{7}$.

${ }^{4}$ Deklaracja z Rio $w$ sprawie środowiska i rozwoju. Konferencja Narodów Zjednoczonych Środowisko i Rozwój na posiedzeniu w Rio de Janeiro w dniach od 3 do 14 czerwca 1992 r., https:// bs.sejm.gov.pl/F? func $=$ find-b\&request $=000000280 \&$ find_code $=$ SYS\&local_base $=$ TEK01 [odczyt: 20.12.2016].

${ }_{5}$ Agenda 21, https://sustainabledevelopment.un.org/content/documents/Agenda21.pdf, dokument na: https://sustainabledevelopment.un.org/outcomedocuments/agenda21 [odczyt:12.12.2015].

${ }_{6}^{6}$ Zob. http://www.unesco.pl/edukacja/dekada-edukacji-nt-zrownowazonego-rozwoju/unesco-a-zrownowazony-rozwoj/ [odczyt: 20.12.2016].

7 Future We Want, http://www.un.org/disabilities/documents/rio20_outcome_document_complete.pdf [odczyt: 20.12.2016]. 
W dyskursie na temat kolejnych szczytów i podejmowanych tam deklaracji najczęściej przewija się wątek tworzenia raczej ogólnej koncepcji niż przygotowywanie konkretnych rozwiązań, które mogłyby być zaadaptowane przez poszczególne państwa. Wymienione powyżej najważniejsze dokumenty ONZ były jednak ratyfikowane przez poszczególne kraje członkowskie, a w rezultacie doprowadziły do szerokiego zainteresowania problematyką zrównoważonego rozwoju. Przygotowany w ramach podsumowania realizacji Milenijnych Celów Rozwoju raport pokazuje, że większości celów nie udało się osiągnąć w wyznaczonym czasie, międzynarodowa mobilizacja na rzecz ich realizacji pozwoliła jednak poprawić warunki życia setek milionów ludzi na całym świecie ${ }^{8}$. W związku z wolą kontynuacji, na Szczycie Zrównoważonego Rozwoju Narodów Zjednoczonych w Nowym Jorku, który podsumowywał realizację Milenijnych Celów Rozwoju, przyjęto nowy dokument zwany popularnie Agenda Post-2015, w którym sformułowano 17 Celów Zrównoważonego Rozwoju (Sustainable Development Goals, SDG) i konkretne zadania (169), które mają zostać zrealizowane do roku 2030 i być monitorowane za pomocą odpowiednich wskaźników. W ostatnich latach można również zaobserwować tworzenie mechanizmów wdrażających koncepcję i przenoszących ją do dokumentów strategicznych. W obszarze obejmującym Unię Europejską niewątpliwie na uwagę zasługuje przygotowana i wdrażana od roku 2010 Europa 2020 - strategia na rzecz inteligentnego i zrównoważonego rozwoju sprzyjającego właczeniu społecznemu ${ }^{9}$, gdzie wśród celów strategicznych został zapisany rozwój w kierunku gospodarki efektywnie korzystającej z zasobów, bardziej przyjaznej dla środowiska i konkurencyjnej ${ }^{10}$. Strategia ta wyznacza kierunki rozwoju państw członkowskich Unii, w tym także Polski, która na jej podstawie (oraz dokumentów wcześniejszych) tworzy własne dokumenty strategiczne na poziomie kraju, regionu oraz dla poszczególnych sektorów gospodarki.

Raport Brundtland (1987) jest najistotniejszym i najczęściej cytowanym dokumentem w dyskusjach o zrównoważonym rozwoju. Choć kultura nie jest szczególnie akcentowana w raporcie, ma kluczowe znaczenie jako wyznaczająca wartości i wzorce. Już w rozdziale 1 pojawia się sformułowanie, że aby skutecznie rozwijać globalne problemy, musimy opracować nowe sposoby myślenia, opracować nowe kryteria moralne $i$ wartościowe $i$, nie ulega wątpliwości, nowe wzorce zachowańn ${ }^{11}$. Raport ten jest również często cytowany przez osoby zajmujące się zarządzaniem kulturą, wyznaczył bowiem i tutaj nowe kierunki rozwoju. Zajmował się tym już w latach osiemdziesiątych i dziewięćdziesiątych ekonomista kultury David Throsby, ale dopiero stosunkowo niedawno dyskusja przybrała na sile. Niewątpliwie przyczyniły się do

8 The Millennium Development Goals Report 2015, UN New York 2015, http://www.un.org/ millenniumgoals/2015_MDG_Report/pdf/MDG\%202015\%20rev\%20\%28July\%201\%29.pdf

9 Europe 2020 - A strategy for smart, sustainable and inclusive growth, European Commision, Brussels, 3.3.2010, Com (2010), http://ec.europa.eu/eu2020/pdf/1_PL_ACT_part1_v1.pdf [odczyt: 15.10.2014].

${ }^{10}$ Oczywiście, zapisy dotyczące zrównoważonego rozwoju pojawiały się również w poprzednich dokumentach strategicznych Unii, np. w strategii lizbońskiej z $2000 \mathrm{r}$.

11 WCED Brundtland Commission: Our Common Future, Oxford 1987, s. 38. 
tego kolejne działania UNESCO, agendy ONZ, która w następstwie przyjmowanych na zgromadzeniu ogólnym dokumentów przenosiła je na obszar, za który jest odpowiedzialna. Są to więc np. dokumenty propagujące dziedzictwo kulturowe (począwszy od Konwencji w sprawie Światowego Dziedzictwa Kulturalnego i Naturalnego Ludzkości z 1972 roku $^{12}$ i tworzenie Listy Światowego Dziedzictwa UNESCO), różnorodność kulturową (Konwencja w sprawie Ochrony i Promowania Różnorodności Form Wyrazu Kulturowego z 2005 roku $^{13}$ ), aż po dokumenty z ostatnich lat, będące bezpośrednim następstwem działań innych jeszcze organizacji i czasem również ich współpracy z UNESCO. Agenda 21 dotyczaca kultury była pierwszym ogólnoświatowym dokumentem (sygnowanym przez ponad 650 miast, samorządów lokalnych i organizacji z całego świata), ustanawiającym zasady i zobowiązania miast oraz samorządów w kontekście rozwoju kultury ${ }^{14}$. W roku 2010 United Cities and Local Governments (UCLG) - globalna sieć zrzeszająca miasta, samorządy lokalne i stowarzyszenia komunalne spośród 120 krajów zrzeszonych w ONZ na całym świecie - na Światowym Kongresie w Meksyku zatwierdziło dokument Culture: Fourth Pillar of Sustainable Development ${ }^{15}$. Angażuje on samorządy, wskazując na relacje między kulturą a zrównoważonym rozwojem poprzez podwójne ujęcie, z jednej strony - przez rozwijanie polityki kulturalnej, w której kultura jest traktowana jako motor rozwoju, a z drugiej - przez promowanie wymiaru kulturowego we wszystkich politykach publicznych (kultura jako czynnik rozwoju). UNESCO zawdzięczamy współczesną szeroką definicję kultury, która obejmuje dziedzictwo w rozumieniu ogólnym i osobistym, wytwory twórczości ludzkiej, dobra, usługi, treści, które są powiązane z koncepcją dobrobytu społeczno-ekonomicznego (wellbeing) i zrównoważonym rozwojem. Ostatnim z dokumentów była deklaracja Placing Culture at the Heart of Sustainable Development Policies, znana też jako Hangzhou Declaration ${ }^{16}$, od miejscowości w Chinach, gdzie odbył się w 2013 roku Międzynarodowy Kongres UNESCO, skupiający się na powiązaniach między kulturą a zrównoważonym rozwojem. Na kongresie, z udziałem społeczności globalnej i głównych zainteresowanych stron międzynarodowych, praktyków kultury, zarządzających, naukowców badających problematykę, omawiano sposoby wzmocnienia roli kultury w ogólnoświatowej dyskusji o zrównoważonym rozwoju i przyjęcie jej za motor wszelkiego rozwoju.

12 Convention on the World Cultural and Natural Heritage of Humanity, UNESCO 1972, http:// whc.unesco.org/en/conventiontext/ [odczyt: 12.10.2014].

${ }_{13}$ Convention on the Protection and Promotion of Diversity of Cultural Expressions, UNESCO 2005, http://unesdoc.unesco.org/images/0014/001429/142919e.pdf [odczyt: 12.10.2014].

${ }_{14}$ Agenda 21 for culture, Agenda 21 2008, http://www.agenda21culture.net/ [odczyt: 12.10.2014], http://www.agenda21 culture.net/sites/default/files/files/documents/multi/ag21_en.pdf [odczyt: 12.10.2014].

15 Culture: Fourth Pillar of Sustainable...

${ }_{16}$ Placing Culture at the Heart of Sustainable Development Policies, UNESCO 2013, http:// www.unesco.org/new/fileadmin/MULTIMEDIA/HQ/CLT/pdf/final_hangzhou_declaration_english. pdf [odczyt: 12.10.2014]. 
Wszystkie wspomniane wcześniej działania znalazły swoje odniesienia dla globalnej polityki kulturalnej. Przykładem tego są strategie wdrażania koncepcji zrównoważonego rozwoju w kontekście kultury, takie jak np. wspólny dokument International Federations of Arts Councils and Culture Agencies (IFACCA), Coalitions for Cultural Diversity (IFCCD), Agenda 21 for Culture i Culture Action Europe Culture as a Goal in the Post-2015 Development Agenda. To właśnie tutaj, w dokumencie będącym wynikiem współpracy organizacji rządowych, pozarządowych i ogólnie środowisk kultury, pojawia się sformułowanie o zapewnieniu stabilności kulturowej dla dobrego samopoczucia wszystkich ${ }^{17}$.

Wśród innych ważnych dokumentów strategicznych należy wymienić również Culture 21: Actions Commitments on the role of culture in sustainable cities ${ }^{18}$, który uzupełnia Agendę $21 \mathrm{w}$ zakresie kultury i przekształca ją w konkretne zobowiązania i działania, ma być międzynarodowym przewodnikiem i zestawem narzędzi dla miast oraz m.in. wspierać działania i współpracę pomiędzy zarządzającymi a mieszkańcami. Dokument ten ma charakter bardziej roboczy, stanowi podstawę do budowania strategii na poziomie lokalnym i wzajemnego wspierania się w tworzeniu, a także monitorowaniu konkretnych narzędzi.

\section{Partycypacja społeczna jako instrument zarządzania}

Partycypację można zdefiniować jako bezpośrednie i pośrednie, sformalizowane i niesformalizowane, indywidualne i kolektywne uczestnictwo obywateli w podejmowaniu $i$ wykonywaniu decyzji dotyczacych dobra wspólnego ${ }^{19}$. Aby nastąpiła, obywatele, a także inni interesariusze muszą być aktywni. Głównymi determinantami poziomu partycypacji są:

- Przeszłość historyczna społeczności

- Charakterystyka powiązań społecznych

- Tradycje kulturowe

- Konflikty

- Władza

- Przywództwo

- Jasna i akceptowalna wizja rozwoju ${ }^{20}$.

17 Culture as a Goal in the Post-2015 Development Agenda, http://www.afai.org.za/wordpress/wp-content/uploads/Culture_as_a_goal_in_the_post-2015_development_agenda.pdf [odczyt: 20.12.2016].

${ }_{18}$ Culture 21: Actions Commitments on the role of culture in sustainable cities, UCLG, Agenda 21 for culture, 2015, http://agenda21 culture.net/sites/default/files/files/culture21-actions/c21_015_ en.pdf [odczyt: 12.10.2016].

19 A. Olech, Modele partycypacji, Jak obywatele moga uczestniczyć w sprawowaniu władzy, Instytut Spraw Publicznych 2010 prezentacja, http://www.isp.org.pl/uploads/filemanager/modelepartycypacji.pdf [odczyt: 12.10.2016].

20 Za: J. Kwiatkowski, Partycypacja społeczna i rozwój społeczny, Warszawa 2003. 
Główną osią jest tutaj, wynikający z przeszłości, poziom integracji lokalnej społeczności. W miejscach, w których nie ma takiej tradycji, można zaobserwować z jednej strony niską skłonność do współpracy, niski poziom kapitału społecznego, z drugiej zaś silnie zhierarchizowaną strukturę administracji - w Polsce wpływ tego czynnika do dzisiaj jest widoczny np. na poniemieckich ziemiach przejętych po roku 1945 bądź takich, w których przeprowadzono duże akcje przesiedleńcze. Dopiero w ostatnich latach, a zwłaszcza po ustabilizowaniu się sytuacji w kraju po przystąpieniu do Unii Europejskiej w 2004 roku, widać w takich regionach zwiększone zainteresowanie miejscem, w którym ludzie żyją nieraz już od dziesiątków lat. W pewnym sensie połączył ich z sobą również brak tradycji i wspólnych korzeni, gdyż przez dziesięciolecia panowało przekonanie, że miejsca, w których żyją, są tymczasowe, nie należą do nich, kiedyś wrócą prawowici właściciele i odbiorą swoją własność. Dopiero gdy mieszkańcy zobaczyli, że mimo otwarcia granic tak się nie dzieje, bardziej zainteresowali się tym, jak poprawić socjoekonomiczne warunki życia (wellbeing), jak wspólnie podejmować działania, jak wykorzystać ów swoisty brak dziedzictwa dla rozwoju.

Inny typ powiązań społecznych, które można zaobserwować, to próby odnalezienia się w nowych środowiskach, będące rezultatem migracji ludności do mniejszych miejscowości, spowodowanej chęcią poprawienia jakości życia, ucieczki od hałaśliwych i tłocznych wielkich miast. Ludzie nie poprzestają tu na wybraniu innego miejsca do życia, ale w bardzo znaczący sposób wpływają na jego zmianę, próbują odnaleźć się w lokalnej społeczności, poszukują własnej tożsamości i pomysłów na biznes, często będąc siłą sprawczą zmian. Ciekawym przykładem są polskie miasta zrzeszone w sieci Cittaslow, charakteryzujące się dużą liczbą ludności napływowej, wykorzystujące lokalne dziedzictwo kulturowe (zarówno w znaczeniu materialnym, jak i niematerialnym) i budujące nowe społeczności wokół koncepcji zrównoważonego rozwoju opartego na ideach slowlife.

Przy okazji dyskusji na temat wdrażania koncepcji zrównoważonego rozwoju pojawia się wątek rozwoju społeczeństwa obywatelskiego, które wiąże się z istnieniem aktywnych organizacji obywatelskich. Ich zadaniem jest aktywizowanie i wspieranie mieszkańców w rozwiązywaniu problemów najbliższego im otoczenia oraz budowanie małych silnych społeczności. Anthony Giddens zaobserwował, że aby nowy porządek społeczny miał szansę się rozwinąć, muszą zostać spełnione pewne warunki:

- Rząd i społeczeństwo obywatelskie są partnerami

- Odrodzenie społeczności następuje przez zmobilizowanie inicjatyw lokalnych

- Musi nastąpić włączenie trzeciego sektora

- Należy ochraniać lokalną strefę publiczną ${ }^{21}$.

Strategie stosowane przez władze publiczne do ożywienia udziału społeczeństwa obywatelskiego i odzyskania zaufania obywateli do polityki różnią się znacznie pod względem natury i zakresu. Są to zarówno fundusze na projekty i programy mające na celu wspieranie wartości demokratycznych na szczeblu lokalnym, jak i np.

${ }^{21}$ Za: D. Ilczuk, Polityka kulturalna w spoteczeństwie obywatelskim, Kraków 2002, s. 26. 
wykorzystanie nowych technologii w celu ułatwienia zaangażowania publicznego we wdrażaniu polityki, kształcenia i szkolenia zawodowego ${ }^{22}$, czy planowanie partycypacyjne, uznane przez Unię Europejską za jedną z najbardziej innowacyjnych koncepcji promowania demokracji uczestniczącej ${ }^{23}$.

Narzędzia partycypacyjne można podzielić na:

- Bierne narzędzia komunikacji jednostronnej (informacje, komunikaty)

- Narzędzia komunikacji ze sprzężeniem zwrotnym, gdyż wymagają odpowiedzi mieszkańców. Są to m.in. ankiety, spotkania i dyskusje (w tym konsultacje społeczne, debaty publiczne, fora), warsztaty diagnostyczno-projektowe, a także demokratyczne wybory

- Narzędzia partycypacji zaangażowanej, wymagającej inicjatywy ze strony społeczności lokalnej, takie jak np. wyrażanie opinii, protestu lub poparcia przez określoną grupę społeczną, budżet partycypacyjny, konsultacje instytucjonalne prowadzone w sposób równoprawny przez grupy, w skład których wchodzą przedstawiciele urzędu, społeczności lokalnej i zewnętrzni eksperci (np. warsztaty charrette), forum oraz Komisje Dialogu Społecznego ${ }^{24}$.

Do najbardziej interesujących należą te, w których społeczności są aktywne, mają świadomość działania nie tylko w kontekście własnych partykularnych interesów. Coraz więcej z nich możemy zaobserwować również w Polsce. Noszą ciągle znamiona eksperymentów, wspieranych przez władze administracyjne (koncepcja zrównoważonego rozwoju jest kluczowym celem strategicznym rozwoju państwa) i uważnie obserwujących rezultaty. Wśród badaczy problemu bardzo popularne w ostatnich latach stało się więc narzędzie nazywane mapowaniem, które pozwala przede wszystkim na gromadzenie informacji o przedmiocie badania i tworzenie pomostów pomiędzy próbami ich zaklasyfikowania. Pierwszym kluczem wyboru przykładów ilustrujących opisywane zjawiska jest więc właśnie partycypacja zaangażowana i jej narzędzia. $Z$ kilkoma dobrze już opisanymi w literaturze przedmiotu wyjątkami techniki partycypacyjne wykorzystywane w różnych społeczeństwach to zjawiska o charakterze efemerycznym, jednorazowym i trudnym do zaklasyfikowania, a jednocześnie powodujące naśladownictwo, często zmodyfikowane, przez co jeszcze trudniejsze do analizy. Drugim kluczem wyboru stały się działania o charakterze kulturalnym, w szerokim rozumieniu pojęcia słowa kultura - jako elementu wpływającego na ogólny dobrobyt, będącego podstawą jednoczenia się społeczności i mającego na to jednoczenie się największy wpływ. W literaturze przedmiotu pojęcia te nie są na ogół tłumaczone na język polski. Ostatnim kluczem wyboru stała się różnorodność podmiotów stosujących dane narzędzie oraz chęć pokazania ciekawych

${ }^{22}$ G. Sgueo, How the EU budget is spent - Europe for citizens (2014-2020), European Parliamentary Research Service, European Parliament, 2015, http:/www.europarl.europa.eu/thinktank/ en/document.html?reference=EPRS_BRI(2015)564392 [odczyt: 12.12.2016].

${ }_{23}$ Participatory budgeting. An innovative approach, Briefing. European Parliament January 2016, http://www.europarl.europa.eu/thinktank/de/document.html?reference=EPRS_BRI(2016)573894 [odczyt: 12.12.2016].

${ }^{24} \mathrm{Za}$ : Partycypacja społeczna w Polsce. Atlas dobrych praktyk, M. Ćwiklicki, M. Frączek (red.), Kraków 2013. 
działań, również na przykładach polskich. Bardziej szczegółowo zostanie zaprezentowane wykorzystanie takich narzędzi, jak:

Budżet partycypacyjny

- Action Planning

- Open Space

- Projects for Public Spaces

- Organizowanie społecznościowe.

Powyższy wybór jest subiektywny, niemniej jednak wydaje się, że dość dobrze oddaje praktyczne wdrażanie koncepcji zrównoważonego rozwoju.

\section{Wykorzystanie narzędzi partycypacji zaangażowanej - wybrane przykłady}

\section{Budżet partycypacyjny}

Eksperymenty z udziałem społeczeństwa w planowaniu budżetu przeprowadzono w Ameryce Północnej, Afryce, Oceanii, Indiach, Korei, Japonii i Chinach ${ }^{25}$. Wzorem dla Europy stały się doświadczenia Ameryki Południowej - uczestnictwo mieszkańców w projektowaniu lokalnych wydatków w brazylijskim Porto Alegre sięga lat dziewięćdziesiątych ubiegłego wieku. Doświadczenia w tym zakresie mają też inne kraje regionu - Argentyna, Kolumbia, Peru, Meksyk. Od początku XXI wieku kolejne państwa wprowadzały regulacje prawne umożliwiające samorządom bezpośrednią współpracę z obywatelami za pośrednictwem tego narzędzia, choć należy podkreślić, że w wersji pierwotnej celem było przede wszystkim rozwiązanie problemu nierówności w poziomie życia.

Wprowadzanie budżetu partycypacyjnego w Europie wynikało z nieco innych przyczyn. W nastrojach społecznych zaobserwowano m.in. spadek zaufania do władz ustawodawczych i wykonawczych. Jak podaje World Values Survey, zaufanie do polityków między rokiem 1990 a 2006 spadło o 22 punkty procentowe ${ }^{26}$, a tylko w latach 2002-2010 liczba Europejczyków wyrażających niezadowolenie z polityki wzrosła z $31 \%$ do $43 \%{ }^{27}$. Krytykujący obywatele (w tym reprezentujące ich organizacje) nie oszczędzają również dużych organizacji międzynarodowych, takich jak Światowa Organizacja Handlu (WTO), która jest krytykowana za osłabienie demokracji w krajach rozwijających się ${ }^{28}$ czy ogólnie - Unii Europejskiej. Za wprowadzaniem budżetu obywatelskiego stoi potrzeba wzmocnienia społeczeństwa

${ }^{25}$ Hope for democracy - 25 years of participatory budgeting worldwide, N. Dias (red.), 2014.

26 See: A. Clarke, Exploiting the web as a tool for democracy: new ways forward in the study and practice of digital democracy, World Forum for Democracy, 2003, http://www.coe.int/en/web/ culture-and-heritage [odczyt: 7.02.2015].

27 I. Van Biezen, P. Mair, T. Poguntke, Going, going...gone? The decline of party membership in contemporary Europe, „European Journal of Contemporary Research” 2012, nr 51.

${ }^{28}$ Who elected the WTO, „The Economist” 2001. 
obywatelskiego, zwiększenia aktywności przeciętnego obywatela, ale również modernizacja usług publicznych czy zwalczanie korupcji.

Budżet partycypacyjny w różnych formach jest wdrażany w Polsce od roku 2009. W raporcie Participatory Budgeting Worldwide czytamy:

W 2012 r. Polska miała największą liczbę eksperymentów PB w Europie. W lutym 2009 r. przyjęto ustawę po ścisłym dialogu między rządem a organizacjami społecznymi (głównie z Watchdog Poland Civic Network). Odwołuje się ona do 2171 gmin wiejskich i miejsko-wiejskich w kraju oraz promuje tak zwane fundusze sołeckie, specjalne środki, którymi administracje lokalne wspierają demokrację na wsiach, dając ludziom szanse na zmianę środowiska, głosowanie nad priorytetowymi działaniami samorządów lokalnych [...]. Procesy partycypacyjne uruchomione przez fundusze sołeckie można by nazwać modelem rozwoju społeczności ${ }^{29}$.

Powodzenie eksperymentów w wiejskich i miejsko-wiejskich społecznościach zaowocowało tym, że w 2013 roku budżety partycypacyjne pojawiły się również w mniej więcej 3\% polskich miast, stając się instrumentem wdrażania zrównoważonego rozwoju, tworząc swoistą modę na to, gdzie i w jakich sprawach oddaje się głos mieszkańcom. Pojawiają się tu, oczywiście, głosy krytyczne, dotyczące np. niewielkiej części ogólnego budżetu przeznaczonej dla projektów bezpośrednio zgłaszanych przez mieszkańców czy ograniczenia ich zakresu (tylko niektóre z miast pozwoliły mieszkańcom na zgłaszanie projektów w kontekście wszystkich możliwych zadań). Mieszkańcy mogą zgłaszać najróżniejsze projekty, pojawiają się więc i te o charakterze typowych działań kulturalnych, np. w Krakowie poza najbardziej oczywistymi projektami bieżącej poprawy infrastruktury miejskiej czy poszerzania terenów zielonych, wśród propozycji mieszkańców znalazły się m.in. takie:

- Detektywi Historii Dzielnicy. Tworzenie teatru, publikacji, wystaw na podstawie kronik rodzinnych

- Prenumeraty gazet dla biblioteki

- Organizacja kina letniego, powołanie miejsca do organizowania cyklicznych wydarzeń kulturalnych i integracyjnych

- Wytyczenie ścieżek rowerowych wzdłuż trasy kulturowo-rekreacyjnej.

Pierwsze eksperymenty z budżetem partycypacyjnym pokazują, że mieszkańcy zaczynają dostrzegać, iż mają realny wpływ na zarządzanie miastem/gminą. Przy okazji bardzo wyraźnie uwypuklony został problem funkcjonowania dużych miast, w których ludzie migrują pomiędzy dzielnicami bądź w ogóle mieszkają poza miastem. Pierwsze budżety ograniczyły możliwości składania projektów i głosowania do mieszkańców dzielnic, których projekt dotyczył, co spotkało się z ogromnym oburzeniem. Później odstąpiono od tej zasady, zamiast niej wprowadzając elementy identyfikujące mieszkańców i pozwalające na wskazanie, ilu z nich mieszka w miejscu, którego projekt dotyczy, a ilu np. w nim bywa z innych powodów (praca, szkoła

29 Participatory Budgeting Worldwide-Updated Version, Dialog Global25, Y. Sintomer, C. Herzberg, G. Allegretti November 2013, http://www.service-eine-welt.de/en/images/text_material-3651. img [odczyt:15.10.2014], tłum. własne. 
itp.). Mimo iż budżet partycypacyjny w Polsce nie ma jeszcze długiej tradycji, niesie wiele korzyści, które można rozpatrywać z punktu widzenia mieszkańców, jak np.

- integrację mieszkańców wokół ważnych dla nich kwestii,

- przyczynienie się do poprawy jakości życia

oraz z punktu widzenia władz, jak np.

- lepsze poznanie pomysłów i potrzeb mieszkańców,

- poznanie opinii na temat polityki lokalnych władz,

- informacje o praktycznym wdrażaniu koncepcji zrównoważonego rozwoju.

Funkcjonowanie budżetów jest bardzo szczegółowo analizowane i opisywane w literaturze przedmiotu. Robi to każda jednostka samorządu terytorialnego, a ewaluacja wykonania jest publicznie dostępna; organizacje pozarządowe prowadzą własne statystyki i podsumowania ${ }^{30}$. Coroczna ewaluacja i możliwość porównywania rezultatów pozwalają uniknąć błędów i uczą również samorządy rzeczywistej współpracy z mieszkańcami.

\section{Action Planning}

Action Planning to narzędzie, które pozwala na skupienie się na osiąganiu wyznaczonych celów. Wymaga przygotowania planu działania, harmonogramu. Umożliwia identyfikację potrzeb i zdefiniowanie problemów w kontekście lokalnym przez bezpośredni udział lokalnej społeczności, dyskusję i wspieranie partycypacji ludzi. Jest praktykowany w miastach w celach identyfikacji problemów danego obszaru i planowania rozwoju, rewitalizacji. W procesie biorą udział lokalne grupy interesu, składające się z ekspertów z różnych dziedzin (m.in. urbaniści, architekci), ale także z mieszkańców danego obszaru. Próbują oni wspólnie znaleźć rozwiązania diagnozowanych problemów.

Do mocnych stron Action Planning można zaliczyć:

- Zwiększenie wiedzy społeczeństwa na temat złożoności problemów

- Obejmuje również osoby, które nie zdecydowałyby się zaangażować same z siebie; zaproszone do dyskusji i planowania, czują się jednak zobowiązane do podjęcia działania

- Pokazuje różnice pomiędzy opiniami ludzi świadomych i nieświadomych istniejących problemów

- Jest dobrym sposobem pomiaru różnorodności opinii publicznej.

Słabe strony:

- Wysokie koszty organizacji procesu

- Wymaga wykorzystania mediów do podnoszenia świadomości publicznej

- Nie dostarcza informacji jakościowych ${ }^{31}$.

Dobrą ilustracją wykorzystania tego narzędzia jest rozwój sieci Cittaslow. Początki Slow Cities (Cittaslow) sięgają roku 1998, gdy organizacja Slow Food spotkała

${ }^{30}$ Np. W. Kębłowski, Budżet partycypacyjny. Ewaluacja, Instytut Obywatelski 2013; czy portal budzetyobywatelskie.pl, gdzie są prezentacje samorządów [odczyt: 16.10.2014].

${ }^{31}$ Zob. http://participationcompass.org/article/show/136) [odczyt: 10.12.2016]. 
się z burmistrzami miast Bra (Cuneo), Greve in Chianti (Florencja), Orvieto (Terni) i Positano (Salerno), aby zaproponować im utworzenie międzynarodowej sieci miast zrzeszonych w Slow Cities. Pomysł się spodobał, bardzo szybko do sieci zaczęły przystępować kolejne miasta, spełniające wyjściowe kryteria: liczba mieszkańców nie przekracza 50 tysięcy, celem strategicznym jest poprawa jakości życia mieszkańców i zrównoważony rozwój. Sieć Cittaslow w Polsce funkcjonuje od 2005 roku, formalnie zarządzają nią władze regionalne województwa warmińsko-mazurskiego. W skład wchodzi kilkanaście miast $\mathrm{z}$ tego regionu i pojedyncze spoza niego: Lidzbark Warmiński, Biskupiec, Bisztynek, Lubawa, Murowana Goślina, Nowe Miasto Lubawskie, Olsztynek, Reszel, Ryn, Gołdap i Olsztyn.

Wśród kluczowych obszarów zapisanych w regulaminie sieci znajduje się adaptacja koncepcji zrównoważonego rozwoju, mająca na celu poprawę jakości życia mieszkańców i budowania poczucia tożsamości lokalnej opartej na wspólnym dziedzictwie. Ważnym czynnikiem wspierającym współpracę na poziomie lokalnym jest wspólna i klarowna wizja rozwoju - bez poparcia społecznego i klarownych planów miasta te nie byłyby w stanie realizować idei sieci Cittaslow. Wykorzystanie narzędzi Action Planning przekazuje odpowiedzialność za realizację polityki zrównoważonego rozwoju w ręce zarządzających siecią i mieszkańców. To oni zgłaszają kolejne inicjatywy i realizują je, planują dalszy rozwój i wytyczają główne kierunki, tworząc wspólne podstawy rozwoju. Większość miast podejmuje działania zmierzające do budowania wspólnych działań i programów, które mają wychodzić naprzeciw potrzebom lokalnej społeczności, mocno w tym podkreślając rolę dziedzictwa kulturowego, które jest czynnikiem identyfikującym i odróżniającym poszczególne miejsca od siebie.

\section{Open Space Technology (OST)}

Narzędzie nazywane też po prostu Open Space, przypisywane Amerykaninowi Harrisonowi Owenowi, który w latach osiemdziesiątych zaczął lansować tezę, że nieoficjalne spotkania i rozmowy są dużo bardziej efektywne niż formalne. W trakcie pracy, gdzie nie ma żadnego z góry narzuconego planu, wszyscy muszą wiedzieć, co chcą osiągnąć i jaki jest ogólny temat spotkania. Na początku wokół tematu przewodniego wydarzenia uczestnicy identyfikują problemy, które chcą poruszyć podczas procesu, potem wpisują się na listę z tematami dyskusji, w której chcą wziąc udział. Sami tworzą plan pracy, a następnie zajmują się tym, co najbardziej ich interesuje. Metoda ta tworzy bardzo płynne i dynamiczne rozmowy, które wynikają z zainteresowania daną sprawą. Narzędzie Open Space sprawdza się, gdy chcemy zająć się kompleksowymi tematami, gdy tematy te mogą wywołać konflikt, gdy podjęcie danego problemu wymaga zaangażowania większej grupy ludzi. Ważnym elementem procesu są pisemne sprawozdania z wszystkich prowadzonych sesji dostępne pod koniec każdego dnia. Konferencja kończy się planowaniem działań, za których realizacje biorą odpowiedzialność uczestnicy. 
Mocne strony tego narzędzia to:

- Metoda sprawdza się szczególnie wtedy, gdy sprawa, której dotyczy, charakteryzuje się wysokim stopniem złożoności, gdy sprawa angażuje uczestników oraz gdy uczestnicy posiadają wysokie i zróżnicowane kompetencje

- Gromadzi wielu zróżnicowanych ludzi

- Wyzwala kreatywność

- Jest niezwykle elastycznym procesem

- Buduje poczucie wspólnoty oraz lepsze warunki współpracy

- Koszty organizacji są niskie ${ }^{32}$.

Ciekawą ilustracją tego narzędzia mogą być niektóre metody pracy polskiego ruchu społecznego, jakim są Obywatele Kultury. To raczej proces, a nie organizacja, ruch reformatorski, domagający się zmian w sferze kultury, które umożliwią pełne wykorzystanie potencjału społecznego zaangażowania, twórczej energii obywateli i wielkości kulturowego dziedzictwa ${ }^{33}$. Ukonstytuował się w maju 2011 roku, za główne cele stawiając sobie budowanie porozumienia między społeczeństwem a władzami publicznymi przez wpływanie na działalność tych drugich, również w kontekście wprowadzenia koncepcji zrównoważonego rozwoju do najważniejszych dokumentów państwowych - w tym także dotyczących kultury.

Jedynym formalnym tworem był, działający do roku 2016, ponadresortowy Zespół do spraw Paktu przy Kancelarii Prezesa Rady Ministrów (KPRM), złożony z przedstawicieli administracji rządowej, samorządów terytorialnych, organizacji społecznych oraz Obywateli Kultury. Był on rezultatem stworzenia przez ruch (na tym etapie złożonego z przedstawicieli środowiska kultury i sztuki) i podpisanego przez Ministra Kultury w 2011 roku Paktu dla Kultury. Zespół ten - kierując się zasadą równej reprezentacji organizacji społecznych, instytucji kultury, związków twórczych, samorządu i administracji rządowej - powołał Komitet Społeczny do spraw Paktu przy Ministrze Kultury i Dziedzictwa Narodowego.

Obywatele Kultury od tamtej pory pojawili się w wielu miastach Polski, jako podstawowe narzędzie wykorzystując Open Space, np. w Krakowie po wstępnych dyskusjach na forach internetowych (m.in. Facebooku) odbywały się spotkania stolikowe, w których brali udział mieszkańcy miasta (musieli się wcześniej zarejestrować). Miały charakter tematyczny, odbywały się pod opieką moderatora i były poświęcone rozmowom na takie tematy, jak:

- Edukacja kulturalna

- Instytucje kultury

- Dziedzictwo kulturowe

- Środowiska twórcze

- Luki: offy, peryferia, obrzeża

- Festiwale

- Miejskość i kultura miejska

- Organizacje pozarządowe.

${ }^{32}$ Zob. http://participationcompass.org/article/show/140 [odczyt: 12.10.2016].

${ }_{33}$ Zob. www.obywatele kultury.pl [odczyt: 12.10.2016]. 
$\mathrm{Na}$ Facebooku pojawiły się raporty z dyskusji. W jednym z nich można przeczytać, że:

[...] postanowiliśmy przeformułować spotkania stolika w działania, które przyniosą nam doświadczenia partycypacji. Konferencja - warsztat - otwarta debata i wszystko formule BarCampu i atmosferze pracowni przygotowującej zmianę społeczną.

W innym pojawił się postulat demokratyzacji oraz zrównania szans i możliwości - na kilku poziomach: 1) zwiększenia uczestnictwa mieszkańców (dążenie do zniesienia bariery finansowej) 2) konsultacji programowych (rodzaj społecznych rad programowych?) 3) sięgania po miejscowy potencjał twórczy, 4) stworzenia mechanizmów do zaistnienia nowych inicjatyw i form aktywności.

Wśród uczestników spotkań pojawiła się potrzeba sformalizowania działań, wynikająca z przekonania, że tylko forma ustrukturalizowana daje możliwość dotarcia z postulatami do właściwych organów publicznych, w ostatnim czasie działania tego ruchu nie są już tak intensywne.

\section{Projects for Public Spacies}

Celem jest tworzenie i utrwalanie istnienia użytecznych miejsc publicznych oraz budowanie silnych społeczności lokalnych, communities. Narzędziem jest tu placemaking - ulepszanie przestrzeni. Wykorzystuje powiązania kulturowe, ekonomiczne, społeczne i ekologiczne, które definiują miejsce i wspierają jego ciągły zrównoważony rozwój. Placemaking to zarówno proces, jak i filozofia, związane z budowaniem lokalnej wspólnoty, jako narzędzie wykorzystywane wcześniej w Stanach Zjednoczonych w latach wielkiego kryzysu lat trzydziestych, okazało się ciekawe dla współczesnej Europy i właśnie tu jest coraz częściej wykorzystywane.

Przykładem ilustrującym mogą być działania o charakterze community gardens, rozwijające się i adaptowane w wielu miastach Europy. Do najciekawszych przykładów należą np. ogrody w Barcelonie, Prinzessinnengarten - mobilny ogród społeczny w Berlinie, Berlin Tempelhof, na terenie zamkniętego lotniska, gdzie jest tylu chętnych do zasadzenia czegoś swojego, że trzeba ustawiać się w kolejce, Urban Physic Garden - miejski, tymczasowy ogród z roślinami leczniczymi, kawiarnią i bogatym programem wydarzeń kulturalnych w Londynie, Edible Park (Jadalny Park) publiczny ogród warzywny w Hadze czy Incredible Edible, czyli Todmorden w Wielkiej Brytanii.

Działania o podobnym charakterze podjęto w czasie jednej z edycji wieloletniego programu w ramach sieci Synaxis Baltica, którego byłam polskim koordynatorem. W roku 2009 Letnia Akademia dla studentów zarządzania kulturą (bo wzajemne wsparcie w tym zakresie było głównym celem programu) została zorganizowana w Poczdamie, w Niemczech, pod dźwięcznym tytułem Menedżerowie kultury pomiędzy rumiankiem a marchewka. Studenci w sposób praktyczny, gdzieś pomiędzy zarządzaniem i animacją kultury, podjęli takie wątki, jak społeczne ogrodnictwo (Community Gardens) oraz partyzantke ogrodnicza (Guerrilla Gardering). Po przygotowaniu merytorycznym realizowali wspólnie z lokalną społecznością liczne 
działania edukacyjne i animacyjne wśród dzieci oraz młodzieży, flash moby zwracające uwagę na problemy braku wystarczającej ilości zieleni, aż po partyzanckie nocne sadzenie kwiatów i krzewów.

Idea Community Gardens rozwija się w Polsce ostatnio bardzo intensywnie i doskonale wpisuje się również w modę na organizowanie społecznościowe - wątek rozwinięty poniżej.

\section{Organizowanie społecznościowe}

Organizowanie społecznościowe jest procesem długoterminowym, który polega na angażowaniu się ludzi w działania na rzecz dobra wspólnego poprzez identyfikowanie i rozwiązywanie przez nich lokalnych problemów. Mieszkańcy mają udział w procesie podejmowania decyzji, które dotyczą osiedli, wsi, miast. Może ono występować w różnych formach (np. organizacji pozarządowych, wspólnot mieszkaniowych), ale też może nie być w żaden sposób sformalizowane. Zostało zainicjowane w Stanach Zjednoczonych w latach trzydziestych XX wieku, gwałtownie rozwinęło się na przełomie lat sześćdziesiątych i siedemdziesiątych, również w Europie.

Organizowanie społecznościowe przejawia się w rosnącej liczbie spontanicznych inicjatyw, które przyciągają coraz większe rzesze odbiorców, odbywają się dzięki chęci i zaangażowaniu mieszkańców. Do takich należą np. miejsca sąsiedzkich spotkań, inicjatywa, która zdobywa w Polsce ogromną popularność. Jedną z nich są ogrody społeczne, których tworzenie jest inspirowane opisanymi wcześniej przykładami i odbywa się coraz częściej, przy wsparciu i patronacie władz lokalnych i ogólnopolskich. Celem jest poznawanie sąsiadów, wymiana doświadczeń, wzajemna pomoc przy okazji wspólnego tworzenia ogrodu.

Inna inicjatywa zaczęła się $\mathrm{w}$ ramach projektu przygotowanego na międzynarodowy festiwal sztuki w przestrzeni publicznej Artboom w 2013 roku w Krakowie. "Cafe Fińska” miała trwać tyle, ile festiwal - dwa tygodnie, ale przetrwała kolejne lata. Miejscem spotkań stał się lokal, za który czynsz był płacony za pośrednictwem crowdfuningu lub zbiórek wśród przychodzących. Na Facebooku można było śledzić wydarzenia: wieczory z teatrem, tematyczne kolacje, występy kabaretu, wieczory filmowe, koncerty, pokazy chemiczne, warsztaty recyklingu, a także eksperymentalne improwizacje i pikniki. Do dziś można tam też przeczytać, o czym dzisiaj się rozmawiało, zobaczyć rysunki, jakie powstały na obrusach. Stała się miejscem dla sąsiadów, ale tworzonym również przez muzyków, kabareciarzy, nieformalną grupę literacką, naukowców, tłumaczkę, socjologa, striptizera czy gości z innych miast. Wśród bywalców dużo było studentów i freelancerów. To przede wszystkim miejsce, w którym najważniejsza była rozmowa, wymiana myśli, ale jednocześnie ścierały się tam różne koncepcje dotyczące funkcjonowania bezgotówkowej kawiarni - czy ma być bardziej miejscem, które integruje społeczność lokalną, miejscem działań społecznych czy terapeutycznych, czy miejscem spotkań artystycznych. „Cafe Fińska” borykała się cały czas z problemami finansowymi i choć trwały dyskusje o sformalizowaniu struktury, rozmowy o współudziale miasta Kraków we współfinansowaniu, to „Fińska” tego nie przetrwała i zakończyła działalność. 
Innym działaniem mogącym ilustrować omawiane narzędzie są krakowscy Pogromcy Bazgrołów, którzy prezentują troskę o estetykę otoczenia, wspierają inicjatywy sąsiedzkie i pomagają w organizowaniu pikników sąsiedzkich, połączonych z zamalowywaniem przez mieszkańców bazgrołów zaatakowanych sprejami budynków. Dzieje się to przy dużej akceptacji władz miejskich. Pierwszy piknik sąsiedzki zorganizowano we współpracy ze spółdzielnią mieszkaniową i radą dzielnicy. Kilkadziesiąt osób w strojach malarskich, $\mathrm{z}$ wałkami w ręku stworzyło trzy murale, które pokryły szpecące napisy na kiosku i altanach śmietnikowych, a towarzyszyła temu atmosfera pikniku. Murale pomagali malować studenci Wydziału Sztuki Uniwersytetu Pedagogicznego w Krakowie.

Organizowanie społecznościowe jest pojęciem bardzo szerokim, można tu podawać wiele przykładów konkretnych działań, ale łączy je wspólne jednoczenie się mieszkańców miasta, dzielnicy, wsi w celu wykonania jakiegoś działania, choćby polegającego na samodzielnym załataniu dziurawej drogi dojazdowej, gdy władze administracyjne się do tego nie kwapią.

\section{Podsumowanie}

Przywołane powyżej przykłady wykorzystania narzędzi zaangażowanej partycypacji zostały umieszczone na mapie dobrych praktyk. O niektórych z nich szeroko opowiadano i pisano $\mathrm{w}$ mediach, niektóre są przywoływane $\mathrm{w}$ dokumentach administracji publicznej, stanowią jedynie niewielką ilustrację zarządzania zrównoważonym rozwojem przez instrument zwany partycypacją zaangażowaną. Niewątpliwie pokazują, że pojęcie zrównoważonego rozwoju, strategie na poziomie krajów, regionów czy miast nie są tylko pustymi słowami, powszechnie używanymi przez polityków, administrację publiczną czy media. Pokazują, że działania władz, poprzez wpisanie do najważniejszych dokumentów strategicznych państwa realizowania m.in. koncepcji zrównoważonego rozwoju, prowadzą do budowania przestrzeni dla coraz większej liczby spontanicznych inicjatyw. Również władze, wybierane przecież jako reprezentacja mieszkańców, dostrzegają coraz częściej, że silna lokalna społeczność i wspólne działanie pozwalają na zbudowanie przewagi konkurencyjnej w globalnym świecie. Zaczynają więc być coraz częściej wykorzystywane, budując lepsze relacje między społecznością a władzami. Można by tu przywołać wiele przykładów porażek przy wykorzystywaniu narzędzi partycypacyjnych, wynikających ze złego przygotowania, braku umiejętności czy otwarcia na społeczność - dobrze to widać w ewaluacjach budżetów obywatelskich czy doniesieniach medialnych na ten temat. Należy jednak zauważyć, że i społeczności lokalne, i administracja publiczna - czasami stojące po przeciwnych stronach - uczą się wzajemnej współpracy. Pojawia się coraz więcej instrumentów zarządzania zrównoważonym rozwojem, ułatwiających funkcjonowanie społeczności zarówno w obszarze gospodarczym, jak i społecznym. Kultura zaś, rozumiana bardzo szeroko, bynajmniej nie jako działalność tylko artystyczna czy upowszechniająca, lecz budująca swoisty 
dobrobyt i przejawiająca się w różnych aspektach życia społecznego, prowadząca do przeorientowania założeń lokalnej i regionalnej polityki rozwoju, staje się i motorem i czynnikiem rozwoju.

\section{Bibliografia}

Agenda 21 for culture, Agenda 21 2008, http://www.agenda21 culture.net/ [odczyt: 12.10.2014].

Clarke A., Exploiting the web as a tool for democracy: new ways forward in the study and practice of digital democracy, World Forum for Democracy, 2003, http://www.coe.int/en/web/culture-and-heritage [odczyt: 7.02.2015].

Convention on the Protection and Promotion of Diversity of Cultural Expressions, UNESCO 2005, http://unesdoc.unesco.org/images/0014/001429/142919e.pdf [odczyt: 12.10.2014].

Convention on the World Cultural and Natural Heritage of Humanity, UNESCO 1972, http://whc. unesco.org/en/conventiontext/ [odczyt: 12.10.2014].

Culture as a Goal in the Post-2015 Development Agenda, Culture 21: Actions Commitments on the role of culture in sustainable cities, UCLG, Agenda 21 for culture, 2015, http://agenda21 culture.net/sites/default/files/files/culture21-actions/c21_015_en.pdf [odczyt: 12.10.2016].

Culture: Fourth Pillar of Sustainable Development, UCLG 2010, http://www.agenda21 culture.net/ documents/culture-the-fourth-pillar-of-sustainability [odczyt: 12.10.2014].

Deklaracja Milenijna Narodów Zjednoczonych, Rezolucja przyjęta na 55 sesji Zgromadzenia Ogólnego Narodów Zjednoczonych, Nowy Jork 2000, dokument przetłumaczony przez Ośrodek Informacji ONZ w Warszawie, czerwiec 2002, http://www.unic.un.org.pl/milenium.php [odczyt: 12.10.2016].

Deklaracja z Rio w sprawie środowiska i rozwoju. Konferencja Narodów Zjednoczonych Środowisko i Rozwój na posiedzeniu w Rio de Janeiro w dniach od 3 do 14 czerwca 1992 r., https:// bs.sejm.gov.pl/F? func $=$ find-b\&request $=000000280 \&$ find_code $=$ SYS\&local_base $=$ TEK0 1 [odczyt: 20.12.2016].

Dahrendorf R., O pojęciu szans życiowych [w:] P. Sztompka, M. Kucia (red.), Socjologia. Lektury, Kraków 2005.

Dias N. (red.), Hope for democracy - 25 years of participatory budgeting worldwide, 2014.

Europe 2020 - A strategy for smart, sustainable and inclusive growth, European Commision, Brussels, 3.3.2010, Com (2010), http://ec.europa.eu/eu2020/pdf/1_PL_ACT_part1_v1.pdf [odczyt: 15.10.2014].

European Governance A White Paper, $\operatorname{COM}(2001)$ 428, http://europa.eu/rapid/press-release DOC-01-10_en.htm [odczyt:12.10.2014].

Future We Want, http://www.un.org/disabilities/documents/rio20_outcome_document_complete. pdf [odczyt: 20.12.2016].

Hausner J. (red.), Komunikacja i partycypacja społeczna, Kraków 1999.

http://www.agenda21culture.net/sites/default/files/files/documents/multi/ag21_en.pdf[odczyt:15.10. 2016].

Ilczuk D., Polityka kulturalna w społeczeństwie obywatelskim, Kraków 2002.

Kębłowski W., Budżet partycypacyjny. Ewaluacja, Warszawa 2013.

Kwiatkowski J., Partycypacja społeczna i rozwój społeczny, Warszawa 2003.

Olech A., Modele partycypacji, Jak obywatele moga uczestniczyć w sprawowaniu władzy, Instytut Spraw Publicznych 2010 prezentacja, http://www.isp.org.pl/uploads/filemanager/modelepartycypacji.pdf [odczyt: 12.10.2016].

Olech A., Kaźmierczak T., Modele partycypacji publicznej [w:] Partycypacja publiczna - o uczestnictwie obywateli w życiu lokalnej wspólnoty, Warszawa 2011. 
Participatory budgeting. An innovative approach, Briefing. European Parliament January 2016,http:// www.europarl.europa.eu/thinktank/de/document.html?reference=EPRS_BRI(2016)573894 [odczyt: 12.12.2016].

Participatory Budgeting Worldwide - Updated Version, Dialog Global 25, Sintomer Y., Herzberg C., Allegretti G., November 2013, http://www.service-eine-welt.de/en/images/text_material-3651.img [odczyt: 15.10.2014].

Partycypacja społeczna w Polsce. Atlas dobrych praktyk, M. Ćwiklicki, M. Frączek (red.), Kraków 2013.

Placing Culture at the Heart of Sustainable Development Policies, UNESCO 2013, http://www. unesco.org/new/fileadmin/MULTIMEDIA/HQ/CLT/pdf/final_hangzhou_declaration_english. pdf [odczyt: 12.10.2014].

Sgueo G., How the EU budget is spent - Europe for citizens (2014-2020) European Parliamentary Research Service, European Parliament, 2015, http://www.europarl.europa.eu/thinktank/en/ document.html?reference=EPRS_BRI(2015)564392 [odczyt: 12.12.2016].

WCED Brundtland Commission: Our Common Future, Oxford 1987.

Who elected the WTO, „The Economist” 2001.

World Conservation Strategy: Living Resource Conservation for Sustainable Development, International Union for the Conservation of Nature and Natural Resources, Gland 1980. 